DIE GEREFORMEERDE SKRIFBESKOUING EN MODERNE METODES VAN VERKLARING VAN DIE NUWE TESTAMENT

J. Botlia

Departement Grieks, PU vir CHO

\title{
ABSTRACT
}

In this article aspects of current exegetical methodology in New Testament studies are evaluated with reference to the reformed doctrine of Holy Scripture. The main aspects of the reformed doctrine of Scripture are discussed. Certain textual-theoretical principles which form the basis of the new methodologies in New Testamant studies are discussed, as well as the most important methodological principle in a textual-theoretical approach and the determining factor of one's concept of the text as such.

Against this background it is argued that the basic underlying aspects of recent methodologies do not conflict with the reformed doctrine on Scripture, but that these have come into being as a necessary and legitimate result of this view on the nature of the Scriptures.

Finally, the author proposes six principles for the future approach which, in accordance with this view, should be adhered to by reformed scholars of the New Testament.

Reeds op die heel eerste bladsye van die Bybel maak ons kennis met die vraag na die verklaring van die woord van God: die slang vra vir Eva: "het fond wriklik gesé julle mag van geen boom in dip tuin eet nie?" (Gen 3:1). Anders gestel: hoe verklaar en interpreteer iy dit wat God gesé het ( = God se woord?)

In die Nuwe Testament is die bekendste voorbeeld van hierdie verstaansproblematipk sekerlik dié van Handelinge 8 waar die hofdienaar van Etiopië besig is om uit die profeet Jesaja te lees. Filippus, gestuur -259-

Koers $51(3) \quad 1986$

ISSN 01)2 3-270X 
deur die Heilige Gees, hardloop na hom en vra: "verstaan u wat u lees?" (vs. 30). Die Etiopiër antwoord: "Hoe sou ek kan verstaan as niemand dit vir my uitlè nie?" (vs. 31). Filippus het toe by die Skrifgedeelte wat die hofdienaar gelees het begin en die evangelie van Jesus Christus aan hom verkondig (vs. 35). Hierna het die hofdienaar tot geloof gekom en is hy gedoop.

Volgens Kuitert (1974:12-14) is veral die volgende vier sake in hierdie gebeure baie opvallend:

- Die doeltreffende funksionering van die Skrif vereis blykbaar dat dit verstaen moet word. Werklike agting en eerbied vir die Heilige Skrif hou dus in dat die vrae wat met die verstaan van die Skrif te doen het, ernstig opgeneem sal word.

- Om die Skrif te kan verstaan is vertolking nodig. Hiervoor neem God mense as instrumente in sy diens, soos in die geval van Filippus.

- Die werk van die Heilige Gees vind plaas in en deur dit alles. Dit is die Heilige Gees wat vir Filippus gestuur het. Die werk van die Gees en die werk van die mens moet dus nie teenoor mekaar gestel word nie. Verstaan, of liewer, tot verstaan bring, is die werk van die Heilige Gees, maar dan nie 'n werk ondanks menslike vertolkers of buite alle vertolkingsarbeid om nie, wel egter via en deur middel van hierdie vertolkers en hulle arbied. Skrifverklaarders wat hulle besig hou met vrae van versfaan en interpreteer is dus nie besig met ongeestelike werk nie, hulle is besig as instrumente van die Gees.

- Dit gaan in die vertolking en verstaan van die Skrif ten diepste oor die verkondiging van die evangelie van Jesus Christus. Dit is dan ook waarvoor die Skrif gebruik moet word, en nie vir allerlei ander dinge nie.

Op Skrifuurlike gronde kan daar dus gekonkludeer word dat die Skrif verklaar moet word. So gesien, kan iemand soos die groot reformator, Calvyn, se uitgebreide verklarings van die skrif bestempel word as gehoorsaamheid aan hierdie Skriftuurlike eis. 
Die beoefening van die teologie is die beoefening van 'n wotenskap. Wetenskaplike skrifverklaring vereis ' $n$ wetenskaplik verantwonrde metodologie. As gevolg van omvattende grondverskuiwings in die metodologie van Skrifverklaring die afgelope twee dekades,' bevind baie eksegete hulle vandag skielik in 'n vreemde wèreld. Lategan (1978:18) bring dil soos volg onder woorde:

"What is happening to biblical exegesis? In recent publications in this field, the most unlikely phrases keep cropping up: "semiology", "actancial level", "deep structure", "narrative syntax". "notifemes", "logical square", "synchronic" and "diachronic", "meaning" and "sense", "paradiginatic" and "syntagmatic.", "signifier" and "signified", to mention just a few of these unfamiliar terms. For exegetes trained in the reserved, understating Anglo-Saxon tradition in the wake of Lightfoot, Taylor, Manson and Dodd, for exegetes steeped in the existentialistic thenlogy of Bultman and committed to the historical critical method, for exegetes from a Reformed background, following mentors like Berkouwer and Ridderbos, the initial introduction to this strange exegetical jargon is often disngrecable, disturbing and even an nunerving experience" (my kursivering - JB)

llierdie reaksie kan volgens Lategan (1978:18) daaraan toegeskryf word dat voorstaanders en benefenaars van tradisionele eksengetiese metodes begryp dat die basiese uilgangspunte van hulle werk bevraagteken word

In die kleiner kring van spesifiek die Gereformeerde Kerke in $\mathrm{SA}$ bestaan daar onder baie ook ernstige vrae of - om le veralgemeen - hierdie

1 Ter motivering van die geldigheid van hiprdie stelling word hier volstaan met 'n verwysing na die volgende twee baie resente artikels van prof. HJ B Combink: Dic pendulum swani turug - enkele opmerkings oor metodes valu Skrifinterpretasip (1983) ell The changing scene of biblical interpretntion (1986) asook die voordrag van prof. B C Lategan op die NTWSA kongres van 1984: Current issues in the hermeneutical debate (1981). 
moderne/nuwe metodes van Skrifverklaring nie ook in botsing is met die gereformeerde beskouing van die skrif nie. Veral wat Gereformeerde Nuwe Testanentici ${ }^{2}$ betref, kan hierdie vraag waarskynlik toegeskryf word aan die reaksie van J.C. Coetzee (1979) op die intreerede van W.S. Vorster (1977) waarin hy Vorster onder meer van 'n onbybelse visie op die Skrif beskuldig. In hierdie rede van hom behandel Vorster juis aspekte van die metodologiese verskuiwing in die eksegese warna so pas verwys is.

Teen hierdie agtergrond is dit sekerlik nie onvanpas om aspekte van die nuwere eksegetiese metodologie te toets aan die belydenis in ' $n$ poging om te probeer vasstel of daar 'n botsing is of nie. Vir die doel word (1) die belangrikste aspekte van die Gereformeerde Skrifbeskouing kortliks uiteengesit aan die hand van verskillende publikasies van Coetzee (1980, 1981 en 1984). Vervolgens word (2) teksteoretiese uitgangspunte wat ten grondslag aan die nuwe metodologie lè, uiteengesit, en word daar gepoog om (3) die belangrikste metodologiese vitgangspunt in " $n$ teksteoretiese benadering aan te toon, asook (4) die deurslaggewende rol van $n$ mens se teksbeskouing in die studie van die Nuwe Testament. Die kwessie van (5) botsing met die Gereformeerde Skrifbeskouing al dan nie word daarna bespreek en ten slotte (6) word gepoog om enkele koersaanduidende opmerkings te maak op grond van die resultaat van die redenasie in 5 .

Ek ervaar geen besondere apologetiese drang met betrekking tot enige spesifieke metode van teksanalise nie. Dit gaan vir my om in eerlike ondersoek na die vraag of metodologiese vernuwing in die eksegese veral met betrekking tot die bydraes hiertoe uit ander dissiplines soos byvoorbeeld die literatuurwetenskap en die linguistiek - inpas binne die grense van die Gereformeerde Skrifbeskouing of nie.

2 Hier bedoel ek spesifiek lidmate van die Gereformeerde Kerke in SA. Gereformeerd met in hoofletter gespel word in hierdie artikel deurgaans met hierdie spesifieke verwysing gebruik terwyl gereformeerd met in kleinletter gespel verwys na die gereformeerde teologie in breëre kring. 
1. RF.I.VANTE, PUNTE VAN DIE. GF.RF.FORMFF.RDF. SKRIFBF.SKOUING;

Vir in kort uiteensetting van relevante punte van die Gereformeerde Skrifbeskouing sluit ek doelbewus volledig aan by die geskrifte van J.

C. Coetzee oor hierdie saak, en wel om die volgende redes

- Coetzee geniet vertroue binne teologiese kringe in die GKSA as konserwatiewe teoloog wat suiwer en Skrifgetrou sy vak beoefen. Ter stawing hiervan kan genoem word dat die artikel van Coetzee, Floor en De Klerk (1980) oor die hermeneuse van die Skrif feitlik in al die proefskrifte en verhandelings wat sedert 1980 a n die Fakulteit Teologie aan die PU vir CHO ingehandig is, aangehaal is.

- In die werke van Coetzee word die gangbare Skrifbeskouing binne die GKSA duidelik en kernagtig uiteengesit.

- Vir die keuse van watter punte van die Gereformeerde Skrifbeskouing vir die onderwerp relevant is, hou ek dus by die sake waaraan Coetzee besonderlik aandag gee. Dit is uiteraard log nie moontlik on ' $n$ hele locus in die dogmatiek (locus de sacra Scriptura) in die kort bestek van 'n artikel te probeer bespreek nie.

\subsection{DIE GESAG VAN DIE BYBEL}

Coetzee (1981:63-71) verduidelik die gesag van die Bybel deur eerstens te wys op die gesag wat die gereformeerde Belydenis aan die Bybel toeken en dan in die tweede plek met omvangryke teksverwysings aan te loon dat die skrif solf ook hierdie gesag vir homself opeis. Coetzee beklemtoon veral die volgende punte:

\subsubsection{Die Bybel is die geinspireerde Woord van God}

Art. 3 van die Nederlandse Geloofsbelydenis wat hieroor handel beklemtoon die volgende drie sake in hierdie verband:

1. Die Bybel is God se geskrewe Woord waarin Hy Hom aan ons openbaar, bekendinaak (Coetzee, 1981:64, Coetzee et al., 1980:15). 
Op hierdie punt verwys Coetzee $(1981: 67-68)$ na die volgende tekste: Heb 1:1, Eks 20:1, Jer 1:4-9, Ps 50:1, Openb 1:1-3.

2. Vir sy openbaring gebruik God wel menslike werktuie, maar Hy dryf of Insplreer hulle sodat hulle nie hulle eie (moontlik sondige en verkeerde gedagtes) uitspreek nie, maar alleen die wil en gedagtes van die Heilige Gees (Coetzee, 1981:64, Coetzee et al., 1980:15). Op hierdie punt verwys Coetzee $(1981: 68)$ na die volgende tekste: Hand 1:16, 1 Kor 14:37, 2 Pt 1:21, Openb 2:7.

3. Die inspirasie geld sowel die gesproke woord as die geskrewe woord, daarom is die Bybel heilige en Goddelike geskrifte (Coetzee 1981:64). Op hierdie punt verwys Coetzee $(1981: 68)$ na die volgende teks: 2 $\operatorname{Tm} 3: 16$ ).

Op grond van die redenasie tot sover konkludeer Coetzee dat die Bybel organies geinspireerd is en dus honderd persent in menslike boek en tegelyk en in die eerste plek ${ }^{3}$ honderd persent in Goddelike boek (Coetzee 1981:64; 1984:19).

\subsubsection{Die Bybel het absolute en onfeilbare gesag}

Artikels 4-6 wat oor hierdie sake handel, beklemtoon volgens Coetzee (1981:65) veral die volgende sake

1. Die Bybel is onweerspreekbar

3 Hoewel Coetzee (1981:64-65) standpunt inneem teen die sg. meganiese inspirasiebeskouing laat sy formulering van hierdie saak in die latere geskrif (1984:19) myns insiens tog die indruk van 'n geneigdheid tot hierdie beskouing: ... "Die Bybel (is) wel 1008 'n menslike boek, maar deur die inspirasie van die Heilige Gees is God die eintlike Skrywer en (is) die Skrif tegelyk en in die EFRSTF. PI.F 100\% in Goddelike boek." (Kursivering van wel en maar is van my, en Coetzee self kursiveer eerste plek). Die twee sake word dus in teenstelling met mekaar gestel en 'n duidelike keuse word gesuggereer. 
2. Die Bybel is volkome geloofwanrdig en die hele Bybel het gesag. Geen deel, hoe klein ook al, is "tydgebonde" of nie gesagliebbend nie.

3. Die Bybel is geheel annsontig (in onderskeid van die apokriewe boeke).

As Skrifbegronding vir hierdie gesagvolheid van die Skrif, verwys Coetzee (1981:69-70) na die volgende tekste: Mt 4:4, 7, 10; Mt 5:17, Jh 10:35; Gal 1:6-8; 2 Pt 1:16-19; Openb 22:18-19.

\subsubsection{Die gerigtheid (skopus) van die Skrifgesag}

God se doel met die Skrifopenbaring is volgens Coetzee (1981:66; 1984:21) en Coetzee et al. $(1980: 23)$ veral die volgende drie sake:

1. God openbaar Homself sodat ons llom sal verheerlik.

2. God maak in die Skrif sy wil aan ons bekend as reël vir ons lewe sodat ons Hom reg kan dien.

3. God wil in die Skrif aan ons dip wrg lot die ewige lewe bekend maak.

As Skrifbegronding vir hierdie siening van die skopus van die Skrif verwys Coetzee (1981:70-71) na die volgende tekste: Eseg 3:10-12; Jh 17:4, 8; Rm 11:33; Ps 119 (veral vss. 99-105), 2 Tm 3:14-17; Jh 20:30-31

\subsection{PERSPICUITAS SACRAE SCRIPTURAE/CLARITAS SACRAE SCRIPTURAE}

Volgens Coetzee (1984:27) is die deursigtigheid of duidelikheid van die Skrif een van die basiese vertrekpunte van Reformasie. Coetzee et al. (1980: 16) bestempel dil as die aksiomatiese van Skrifverstaan, naamlik dat die weg van verlossing duidelik in die Skrif gewys word. Coetzee (1984:27) formulner hierdie beskouing sons volg: "ltiermee $l=$ die belydenis van die perspicuitas. JB) word nie bedoel dat die Bybel géén verstaansprobleme bevat nie. Hiermee word wél bedoel dat die eintlike bedoeling (die skopus) van die Bybel vir errige redelike leser en hoorder -265- 
begrypbaar is. Die boodskap van heil en genade vir 'n verlore en in sonde gevalle mensdom deur wie ook die hele skepping geval het, is daarin helder en duidelik hoorbaar en verstaanbaar vir elkeen wat ore het om te hoor."

Coetzee et al. (1980:16) plaas hierdie belydenisstuk met reg teen die historiese agtergrond van die stryd van die Hervormers teenoor Rome wat geleer het dat die kerklike leeroutoriteit (clerus) tussen die Woord en die gelowige hoorder (Laecus) mót staan indien die laeci die Skrif wil verstaan. Volgens Berkouwer (1967:252) moet hierdie siening van Rome toegeskryf word aan in drang tot beskerming van die Bybel teen willekeurige en individualistiese uitleg en dat Rome se belydenis van die "duisterheid" van die Skrif gesien moet word as ' $n$ besorgdheid teen vrye Bybellees. Hierteenoor het die Reformasie bely dat die boodskap van die Bybel in beginsel tonganklik is in die gelowige se konkrete omgang en verstaan van die Skrif en dat die Woord as sward van die Gees tot beskikking van die gelowige moet wees as noodsaaklike wapen rusting in die stryd teen die bose (Berkouwer, 1967:256). Ek wil dit egter beklemtoon dat hierdie belydenis teen sy historiese agtergrond gesien móét word. Indien dit daarvan losgemaak word, is dit erg problematies.

Berkouwer (1967:247-248) beredeneer die probleen soos volg: mak die belydenis van die deursigtigheid van die Skrif dan nou nie alle vertolking oorbodig nie, veral dan nog as ons verder ook bely dat die Skrif sy eie interpreteerder is? Dit kan tog nie, want dit sou die Skriftuurlike beginsel van die noodsaak tot Skrifverklaring soos dit blyk in Hand 8 , in gedrang bring. Indien hierdie belydenisstuk sou impliseer dat daar geen verstaansprobleem is in die gelowige se omgang met die Bybel nie, warom het Luther en Calvyn hulle dan liulle hele lewe lank intensief met Skrifverklaring besig gehou?

Ook Coetzee et al. (1980:16) stel dit duidelik dat die belydenis van die perspicuitas nie "ons verantwoordelikheid weg (neem) om uit die Bybel self reëls vas te stel vir die verstaan van die Bybel nie. So word misverstande (my kursivering - JB) voorkom of uit die weg geruim." Hoe kan daar dan misverstande wees as ons bely dat die Bybel helder en duidelik is? 
In hierdie verband het Rossouw (1963:333) die volgende verhelderende opmerking gemaak: "In die reformatoriese leer van die clarilas Scripturase word hip dip retoriese deursigtiglieid of probleemlose klaarblyklikheid van die Skrifwoorde op die vlak van algemeen-menslike kenbarheir bely nie, maar veeleer die religieuse openheid van die Skrifteks binne die heilshistories-eskatologiese vertande van die korrelasie tussen die Whord van God en die geloof." Berkouwer (1967:266-267) verduidelik Rossouw se slelling deur daarnp te wys dat die leer van die prorspicnltas nie die duidelikheid van die vorba as sodanig hedoel nie, maar wel die duidelikheid van die res. die saak, die iuhoud van die Heilige Skrif." Dit is "n belydenis van die religieuse duidelikheid van dif evangelie vir die sondaar. Die egten perspicuitas is die innerlike verslaanbaarheid van die Skrif vir die sondaar en daaron kan slegs in terme van geloofsbelydenis oor perspicuitas gepraat word.

P'erspicultas kan dus volgens Rossouw nie op die verla van die Skrif en met nanie hulle semantiese funksie betrek word nie, en 'n mens kan nie anders as om te elken dat die Skrif (as verbale verskynsel) nié in alle opsigle duidelik is nie (Berkouwer 1967:266).

\subsection{SACRA SCRIPTURA SUI IPSIUS INTERPRES}

Coetsee et al. (1980:19-20) beskou dit as die goule reël van Gereformeerde Skrifverklaring en betrek dit veral op die volgende sake (wat Coetzee 1984: 28 "beperkende faktore" noem):

1.3.1 Die Skrif is "n monhoid en die selfinterpretasie van die Skrif is daarin geleë dat Skrif-met-Skrif vergelyking sowel moontlik as noodsaaklik is.

- Rossouw bednel nie hiermee een ol ander skeiding van vorm en inhoud nir. Dit soll egter te breed gaall on sy redentasie hier te probeer weerger en daarnm word volstaan met 'n verwysing na sy proniskrif Klatarheil en Interpretasio (1963). 
1.3.2 Dit ontken egter nie die verskeidenheid van die Skrifte nie. Al bestaan die Bybel uit 66 boeke wat in ongeveer 1300 jaar in verskillende tale en kulture en plekke deur verskillende mense geskryf is, elke boek met in eie literatuurtipe, struktuur en tema, is dit tog in eenheid as gevolg van die inspirasie van die Heilige Gees.

1.3.3 Die openbaringshistoriese ontwikkoling in die skrif is ' $n$ hermeneutiese sleutel. Daarvolgens is 'n latere woord in die Godsopenbaring nor dieselfde saak altyd deurslaggewend teenoor die voorafgaande.

1.3.4 Die verhouding tussen die ou en Nuwe Testnment is by die bepaling van die Skrif van deurslaggewende belang (vgl. hier ook Floor 1984:21-35). Dit hou in dat die eksegeet moet rekening hou met sowel die eenheid van die Skrif as die eie-aard van die onderdele, ook binne die twee Testamente en in die verhouding van die twee Testamente lot mekaar.

1.3.5 Die beginsel van Skrif-met-Skrif-vergelyking moet so toegepas word dat onduideliker uitsprake in die lig van die meer duidelike ultsprake geinterpreteer moet word.

1.3.6 Die Skrif is nie tydgehonde nie mar wel oorwegend tydgerig. Hier onderskei Coetzee (1984:30) tussen in oorgokompliseerde kritiese benadering wat die historiese karakter van die Bybel oorbeklemtoon en die oorvereenvoudigde fundamentalistiese benadering wat die historiese karakter oorbeklemtoon of ignoreer.

Dat hierdie beginsel van Skrif-met-Skrif-vergelyking nie probleemloos is nie, is duidelik uit die rabbynse toepassing daarvan en hulle resultate (Deist, 1984:56). Die rabbyne het deur gebruikmaking van hierdie beginsel byvoorbeeld ' $n$ hele "Eliateologie" ontwikkel (vgl. Coetzee, 1980).

'n Laaste opmerking onder hierdie punt: die feit dat daar in die gereformeerde Dogmatiek in beginsel soos Sacra Scriptura sut ipsius interpres bestaan, erken myns insiens prinsipieel dat daar ' 
hermeneutiese probleem by die lees van die Skrif bostaan en dat die Skrif geïterpreteer moet word.

\subsection{KONGENIALITEIT}

Hoewel die inspirasie van die Skrif deur die Heilige Gees reeds hierbo in 1.1 .1 bespreek is, is dit belangrik om ook meer spesifiek die kwessie van kongenialiteit te noem, aangesien dit wesenlik deel vorm van die gereformeerde Skrifbeskouing. Coetzee (1984:26) formuleer dit soos volg: "Kongentalitift, as tegniese term, beteken ... d die Heilige ciees wat die Skrif geinspireer het en wat in die hart van die ware gelowige leef, is ook die nintlike verklaarder van die Skrif." Coetzee et al. (1980:21) stel dit só:

"Egte eksegese en hermeneuse, waarin gepeil wil word wat die Gees vir die gemeente wil sé, (vereis) volle kongonialiteit tussen die eksegeet en die teks voor hom - die kongenialiteit van dieselfde Gees wat beide teks en eksegeet dra."

In die lig van hierdie uiteensetting van die Gerelormeerde Skrifbeskouing kan myns insiens gekonklisdeer word dat geen belydenisstuk wetenskaplike Skrifverklaring oorbodig verklaar nie. Inteendeel, wetenskaplike Skrifverklaring, die opdrag daartoe en die eis en noodsaak daarvall, is 'n logiese uituloeisel van die Gereformeerde Skrifbeskouing.

Die volgende opmerking van Nixon (1977:347) stel die saak nog verder in "n positiewe lig. As konklusie tot sy artikel oor die gesag van die Nuwe Testament skryf Nixon: "A fearless attempt to interpret the New Testament correctly will do more to strengthen than to undermine its authority. For the authority of the Bible comes home most clearly to us when we understand it as fully as we are able to do" (Nixon, 1977:347).

In die lig hiervan moet daar nou meer spesifiek gekyk word na teksteoretiese uitgangspunte wat ten grondslag lè aan die huidige snelle metodologiese ontwikkelings in die eksegese, om in staat te wees om te kan beoordeel of dit nie dalk in botsing met die Gereformrerde Skrifbeskouing is nie. 


\section{TEKSTEORETIESE UITGANSPUNTE"}

\subsection{DRIE MOMENTE VAN DIE TEKS VAN DIE BYBEL}

in Mens kan die Bybelse teks beskou as in teks waarin hoofsaaklik drie momente onderskei kan word, naamlik 'n historiese, in strukturele en in teologiese moment. Hierdie drie momente hang ten nouste met mekaar saam en nie een van die momente moet ten koste van enige ander moment beklemtoon word nie:

1. Met die historjese moment word bedoel dat die Bybelse teks 'n historiese gegewe in ' $n$ dubbele sin is: Dit is as teks op sigself ' $n$ historiese verskynsel met sy eie geskiedenis, wat met historiese metodes ondersoek kan word, maar dit getuig ook van bepaalde historiese gebeure in die verlede, wat die verwysende of referensiële aspek van die teks genoem word.

2. Met die strukturele moment word bedoel dat die teks in die vorm van 'n bepaalde struktuur tot ons kom, ook in ' $n$ dubbele sin: as taalkode voldoen dit aan bepaalde grammatiese, sintaktiese en semantiese reëls en staan die elemente van die teks in ' $n$ bepaalde verhouding tot mekaar. Maar ook die segginge van 'n bepaalde teks as geheel of van ' $n$ bepaalde skrywer vorm 'n struktuur wat deur analise ondersoek en gesistematiseer kan word.

3. Met die teologiese moment word bedoel die selfgetuienis van die Skrif dat dit die Woord van God is wat as sodanig gelees en verstaan moet word. As ons die teks in sy eintlike bedoeling ernstig wil neem, kan hierdie selfgetuienis van die Skrif nie geïgnoreer word nie en

- Vir hierdie teksteoretiese uitgangspunte sluit ek grootliks aan by die viteensetting van Lategan (1984a). Dit is klasaantekeninge wat op hierdie stadium in ongepubliseerde vorm is. Prof Lategan is besig om dit verder te verwerk en dit sal DV uiteindelik in finale verwerkte vorm gepubliseer word in Inndleiding by din Nuwe Testament Deel 2 , wat handel oor metodeleer. 
sal dit by 'n geslaagde interpretasie in berekening gebring moet word.

\subsection{SAMEHANG TUSSEN DIE DRIE MOMENTE}

Vir die verstaan van die teks is in goeie begrip tussen die samelıang van hierdie elemente onontbeerlik. Hierdie samehang kan verduidelik word aan die hand van die kommunikasiemodel van Roman Jakobson:

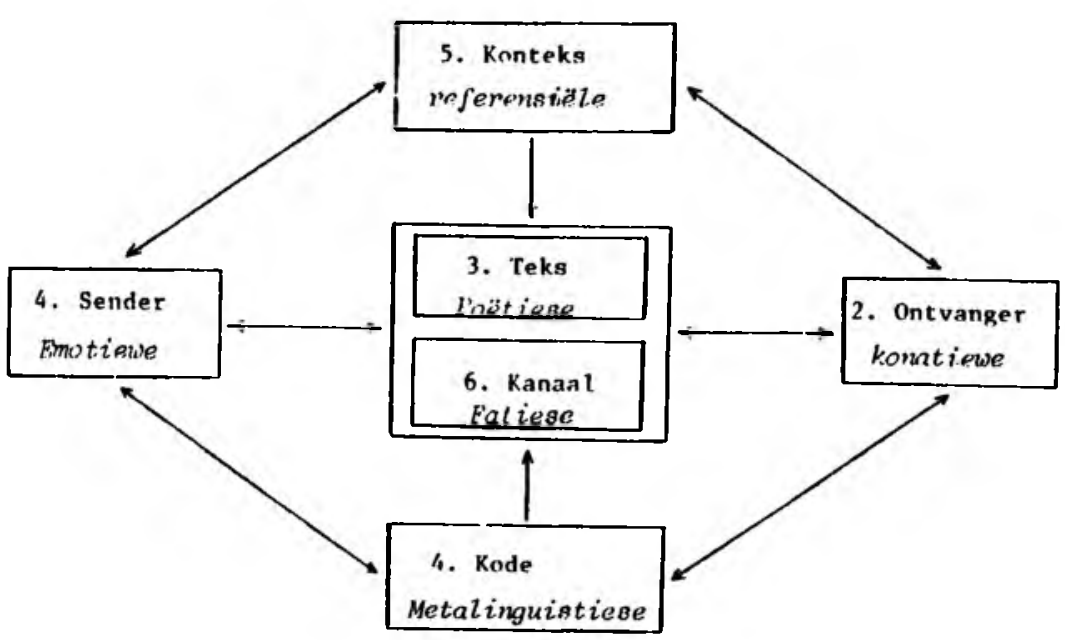

Volgens Jakobson kan ses pole in die kommunikasie-situasie onderskei word: in sender (1) kommunikeer met 'n ontvanger (2) deur middel van 'n teks (3). Die ontvangs van hierdie teks kan egter net slaag as die kode (1) en konteks (5) van die sender en ontvanger ooreenstem. Die kode is die gemeenskaplike taalsisteem wat sender en ontvanger met

- Jakobson se model is oorspronklik gepubliseer in Thomas A Sebeok (ad), Style in langunge, 350-377 onder die tilel l.inguistics and poet Ics. Ek gebruik hier die verwerking darvan deur Güttgemans soos dit deur Lategan (1984a) uiteengesit word.

-271 - 
mekaar verbind en die konteks is die sosiokulturele situasie waarin hulle hulle bevind. Die oordra van die teks vind plaas met behulp van 'n bepaalde kanaal (6) dit is byvoorbeeld klank, skriftekens, elektroniese impulse en simbole. Die taalfunksies wat met hierdie ses pole saamhang is:

1. die emotlewe funksie, dit is die uitdrukking van die "innerlike" van die sender of sy verhouding tot dit waroor hy praat.

2. die konatlewe funksie, dit is die appèl wat deur die taal uitgeoefen word en is dus veral ontvanger-georiënteerd.

3. die poëtlese funksie, dit is die vermoë van die taal om iets te maak (poiein), om ' $n$ teks tot stand te bring. Hierdie funksie moet in hierdie breë sin verstaan word; dit is nie beperk tot slegs die "digterlike" aspek nie. Deur die poëtiese funksie van taal kom teks en literatuur as selfstandige groothede tot stand en is hierdie funksie veral op die teks gerig.

4. Taal funksioneer verder ook as metataal, dit is 'n taal oor taal. Wetenskapstaal is byvoorbeeld 'n metataal, omdat dit in gereflekteerde wyse en in 'n eie kode oor die voorhande werklikheid en dus oor die "gewone" taal praat. Die kode warin die kommunikasievoordrag geskied is by uitstek die plek waar die taal in sy funksie as metataal waarneembaar is.

5. Taal het ook 'n referensiële of verwysende funksie in soverre dit sender en ontvanger verwys na dit warvoor gepraat word en daarom 'n minimum van 'n gemeenskaplike verwysingsveld veronderstel. Hierdie funksie is dus veral op die konteks gerig wat sender en ontvanger verbind.

6. Taal het ook fatiese of seggende funksie in soverre dit sok bloot as klank of simbool kan kommunikeer. Hierdie funksie hang ten nouste saam met die medium wardeur die kommunikasie geskied en is dus gerig op die kommunikastekannal. 
Deur die ses hooffunksies van die taal an die ses pole in die kommunikasiesituasie te koppel is dit moontlik om die belangrikste elemente van hierdie gekompliseerde geheure op in vereenvoudigde wyse in kart te bring.

Breed gesien kan die historiese moment veral in verband met die sender. ontvanger en konteks gesien word en die strukturele monont met die teks. die kanaal en die kode. Waar die teologiese moment inpas sal ek onder punt 5 hieronder probeer aantoon.

\section{BELANGRIKSTE METODOLOGIESE UITGANGSPUNT IN 'N TEKSTEORETIESE BENADERING}

Lategan (1984a) bestempel dit in soveel woorde as die belangrikste metodologiese uitgangspunt dat alle uitleg sy vertrekpunt vanuit die Bybelse teks sal neem. Alle uitleg moet bewustelik onder die dissipline en kontrole van die teks geplaas word. Dit is die enigste wyse warop verseker kan word dat "eksterne" gegewens nie by voorbaat die interpretasie van die teks in 'n bepaalde rigting prejudiseer nie. Historiese, persoonlike, teologiese en ander derglike gegewens kom ter sprake in soverre die teks dit aan die orde stel.

Die keuse van die teks as vertrekpunt is nie willekeurig nie. Die teks vorm die knooppunt van die hele verstansgebeure.

\section{DIE DEURSLAGGEWFNDE BELANGRIKHEID VAN DIE EKSEGEET SE TEKSBESKOUING}

Dit is belangrik on hier te onderskei tussen skrifbrskouing en teksbeskouing. Skrifbeskouing is 'n saak van bolydonis en dit het op 'n eie bepaalde vlak ' $n$ invloed op teksbeskoung, wat 'n wetnnsknpltk-mntorlologinse saak is. Dit is moontlik om binne dieselfde Skrifbeskouing verskillende teksbeskouings te kan hè.

Swanepnel (1981:268-272) noem verskillende moontlike leksbeskouings wat 'n wetenskaplike kall hé, onder andere die volgende: 
1. Die ouere negentiende-eeuse genetiese teorlë̈ wat in die teks belangstel as iets wat deur die skrywer voortgebring en gedetermineer is. Die teks is onder andere bestudeer om iets te wete te kom oor die psige van die skrywer. Hierdie teorie lé in noue verband met Schleiermacher se hermeneutiek (vgl. Rossouw, 1981:22-32) waarvolgens die ware bedoeling van die spreker of skrywer as die singehalte van die betokke taaluitinge gesien word.

2. 'n Tweede groep teorieë plaas die klem ò oorwegend of uitsluitlik op die teks as artefak. Die teks word beskou as 'n outonome artefak wat selfreferensieel is. Hierdie siening van die teks as outosemanties lè ten grondslag aan die sogenaamde teksimmanente eksegetiese modelle soos dit veral in die strukturalisme na vore gekom het (vgl. Vorster 1977:12-17).

3. 'n Derde groep teorieë neem die literère teks op as 'n tekensisteem vir die leser, iets wat deur die leser geaktiveer moet word. Die klem val nie meer op die teks as artefak nie, mar op die teks as tekensisteem wat in die ontsluiting daarvan deur die leser van die artefak tot estetiese objek getransformeer word.

Swanepoel (1984:272-278) toon verder aan hoedat in mens se teksbeskouing belangrike implikasies het vir die metodes wat in die ontsluiting van die teks gevolg word en gevolglik ook vir jou resultate.

Indien akkord gegaan word met lategan (1984a) se stelling dat die teks die knooppunt van alle verstaansgebeure is, kan in die lig van Swanepoel (1984) se redenasie tot die konklusie gekom word dat dit noodsaaklik is dat die eksegeet sy teksbeskouing eksplisint sal maak in sy wetenskaplike werk, aangesien dit 'n deurslaggewende rol in die eksegese speel.

\section{BOTSING?}

Dit is nou moontlik om in die lig van die bespreking tot sover spesifiek aandag te gee aan die vraag of die basiese teksteoretiese uitgangspunte 
soos hierbo uitenngesit, in hotsing met die Gereformeerde Skrifbeskoning is of nis.

\subsection{DIE DRIE MOMENTE VAN DIE TEKS VAN DIE BYBEL}

1. Die historiese moment

Volgens die Gereformeerde Skrifbeskouing is die Bybel corwegend tydgerig (1.3.6) en moet daar rekening gehou word met die openbaringshistoriese ontwikkeling in de Skril (1.3.3). Die feit van dis verskeidenheid in die Skrif (1.3.3) kan aan die historiese karakter van die skrif toegrakryf word.

Van Rooy (1981:115) wys daarny dat, hoewel daar deur konserwatiewe teoluë beswaar ingebring kan word teen die histories-kritiese metodes van Skrifuitleg. dit tog waar is "dat hierdie metodes sekere wettige sake raakgesien het warmee inderdaad rekening gehou moet word." Dieselfde benadering spreek baie sterk lit die boek Nan Tostement Intorprotation onder redaksie van Marshall (1979). Die verskillende kritiese metodes word bespreek, vanuit behoudende kant word die besware daarteen vitgewys, maar die positiewe en bruiktare elemente daarin word ook angetoon

Daar moet dus eriss gemaak word met die historirse moment van die leks van die Bybel.

2. Die stukturde moment

Volgnns die Gereformeerde Skrifbeskouing is die Bybel heilige Goskrifte $(1,1,1.3)$. Mie organiese inspirasietrorre laat dus volle ruimte vir die siening dat die teks van die Bybel as taalkode aan bepaalde laalkundige voorwaardes voldoen en dus 'n taalstruktuur het wat deur analise ondersoek en gesistematiseer kan word. Daar word deesdae redelik algemnen aanvaar dat dip Nuwe Testament in die algemene spreektaal van destyds, Rojni-Grieks, en gevolglik in ooreenstemming met eerste-enuse literére konvonsies geskryl is. 
Die verskiltende metodes van struktuuranalise (bv. dié van Louw (1979), Coetzee (1983) en Van Rensburg (1984) hou liulle besig inet hierdie moment van die Bybetse teks.

Dat struktuuranalise sy beperkinge het is duidelik. Volgens Ricoeur (1975:86) is struktuuranalise op sigself onvoldoende, want dit bly by die verduideliking (Erklarung) van die teks en kom nie uit by die verstaan (Verstehen) van die teks nie.

Ten spyte van hierdie beperking is bair van die insigle van die teksimmanente benadering wel van wesenlike belang om te kom tot in verstaan van die teks van die Nuwe Testament (vgl. Vorster, 1977: 17).

Metodes van teksanalise wat erns maak met die strukturele moment van die teks van die Bybel is dus myns insiens nie noodwendig in botsing met die gereformeerde Skrifbeskouing nie. Trouens, dit word deur Gereformeerdes self gebruik.

3. Die teologiese moment

Dat daar 'n teologiese moment in die teks van die Bybel is, is die kern van die Gereformeerde Skrifbeskouing: die Bybel is die Woord van God (1.1.1)

Dat openbaringshistoriese (of dan teologiese) studie van die teks van die Nuwe Testament in beginsel moontlik en noodsaaklik is, is dus volledig in lyn met hierdie teksteoretiese uitgangspunt.

\subsection{DIE FUNKSIONERING VAN DIE TEKS VAN DIE BYBEL AS KOMMUNIKASIEGEBEURE}

Coetzee (1979:13) se reaksie op Vorster (1977:17) se pleitrede vir 'n interdissiplinère skakeling met die kommunikasiekunde in 'n poging om die probleem in verband met die kommunikeerbaarheid van die Nuwe Testament op te los, is miskien die hoofoorsaak wasrom enige "kommunikasieteorieagtige" terminologie vandag met agterdog bejeën word in Gereformeerde kringe. 
Indien ons egter met Heiberg (1983b:1) saamstem dat die Bybel die openbaring van God bevat waarin God sy wil aan die mens bekend maak sodat hy God kan ken en met Hom leef, dan is die kommunikasie van God se Woord tog 'n uiters belangrike saak. Hoe anders kan God sy wil aan ons bekend mak as Hy nie met ons kammunikeer deur sy Woord nie?

Die teks van die Bybel het tot stand gekom as gevolg van 'n kommunikasiegebeure (inspirasie) en is op sy beurt weer gerig op verdere kommunikasie (verkondiging)(Lategan, 1984a). Om dus wetenskaplik te probeer vasstel watter faktore almal ' $n$ rol speel by 'n kommunikasiegebeure, is myns insiens nie "gevaarlik" of enigsins in botsing met die gereformeerde Skrifbeskouing nie.

Prakties geïllustreer: waar is die rol van die Heilige Gees in byvoorbeeld Jakobson se kommunikasiemodel? Ons bely tog dat die Heilige Gees die eintlike Verklaarder van die Skrif is en dat die Heilige Gees die kommunikasiegebeure beheers?

Indien ons op enige plek in die model 'n blokkie sou trek met Heilige Gees daarin en ' $n$ vaste pyl na een of ander punt in die model, sou ons myns insiens twee vlakke vermeng. Dan mank ons dieselfde tipe fout as wat Richard Rothe in 1863 gemaak het toe hy die taalkundige en grammatikale afwykings van Nuwe-Testamentiese Grieks van Klassieke Grieks daaraan toegeskryf het dat die Nuwe Testament geskrywe is in die "taal van die Heilige Gees" (vgl. Kruger, 1975:28). Behalwe dat dit 'n vermenging van sake is wat op verskillende vlakke figureer, is dit ook 'n oorbeklemtoning van die teologiese moment van die teks ten koste van die ander momente.

Ek dink 'n mens moet dit visueel probeer voorstel deur 'n stippellynkring rondom die geheel van die kommunikasiegebeure te trek en die hele kring met stippellyne in te kleur in 'n poging om aan te toon dat die Heilige Gees op 'n eie unieke vlak en wyse betrokke is by al die faktore in die kommunikasieproses. Hoe presies hierdie betrokkenheid wetenskaplik onder woorde gebring moet word, is 'n aspek waarop ek nie hier 'n antwoord wil probeer waag nie. Die dogmatiese onderskeid tussen iuspiratio en illuminatio word ook nie deur hierdie opvatting in gedrag gebring nie. Dit wil juis die unieke betrokkenheid van die Heilige Gees 
by twee van die ses faktore, naamlik die sender en die ontvanger, verwoord.

Poging tot ' $n$ visuele voorstelling van die rol en plek van die Heilige Gees in die kommunikasiegebeure:

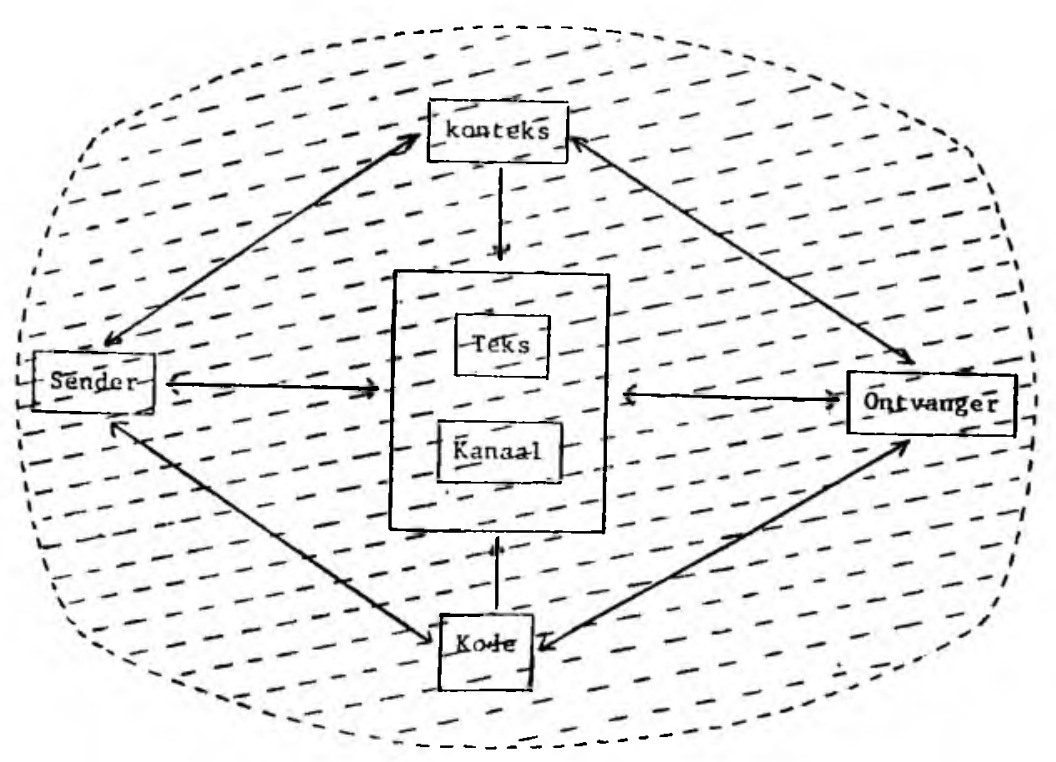

5.3 Die belangrikste metodologiese uitgangspunt in 'n teksteoretiese benadering

Hoe kan ons sè dat die belangrikste metodologiese uitgangspunt is dat alle uitleg sy vertrekpunt in die Bybelse teks sal neem? is dit nie in belangriker uitgangspunt om byvoorbeeld uit te gaan van die kongenialiteit wat daar tussen die Heilige Gees en die eksegeet moet wees in die interpretasieproses nie?

Indien ons hierdie twee sake op dieslefde vlak sou stel, vermeng ons myns insiens weer twee vlakke: 'n "teksteoretiese vlak" en "n "belydenisvlak." Kongenialiteit (en al die ander dinge onder punt 1 genoem) is alles uiters belangrike belydenisuitgangspunte. Voortvloeiend hieruit, maar dan op 'n ander vlak, sè ons die belangrikste metodologiese punt is dat alle uitleg sy vertrekpunt in die teks van die Bybet sal neem.

-278 - 
Indien ons nie van die teks as knooppunt van die kommunikasiegebeure uitgaan nie, kom ons belydenis dat God Homself in sy Woord aan ons geopenbaar het en dat die Gees deur die Woord werk, in gedrang. Dan kan dit geïnterpreteer word as sou ons beweer dat ons tot kennis van die besondere openbaring van God kan kom buite die Woord om.

In plaas daarvan oin hierdie teksteoretiese uitgangspunt as ' $n$ botsing met Gereformeerde Skrifbeskouing te sien, sou ek dit eerder wil bestempel as 'n noodsaaklike en enigste legitieme ultvloeisel van die Gereformeerde Skrifbeskouing.

Ek wil die argument onder hierdie hoofafdeling (of 'n teksteoretiese benadering bots met die Gereformeerde Skrifbeskouing) afsluit met in aanhaling uit Heiberg (1983a:8) se boek Verklaring en Prediking van die Ou Testament:

"Nog 'n kenmerk van God se gemeenskap met ons is dat dit ons geheel-en-al en onvoorwaardelik opeis - met ons verst and en al (my kursivering - J B). Dit beteken nie dat ons verstand uitgeskakel word nie. Die geloof staan nie teenoor ons verstand nie en werk nie daarsonder nie. Die Bybel eis nie van ons ' $n$ onpersoonlike, blinde gehoorsaamheid aan homself of aan God nie, maar stel sy eis teen die agtergrond van iets wat ons verstand kan waarneem, naamlik wat God in sy Woord en die geskiedenis vir ons gedoen het, nou besig is om te doen en nog sal doen. Die Woord maak dus in werklikheid ' $n$ beroep op ons verstand."

Ter afsluiting wil ek 'n paar opmerkings maak oor hoe ek meen ons as Gereformeerde studente van dic Nuwe Testament in die toekoms met ons verstand (wat God aan ons gegee het!) ons vak moet beoefen.

\section{KOERSAANDUIDINGS}

6.1 Ons moet versigtig wees dat die tradisionele negat fwiteit onder gereformeerdes jeens die histories-kritiese metodes nie somaar so deurwerk en ons by voorbaat negatief stem teenoor alle nuwere metodologiese ontwikkelings in die studie van die Nuwe Testament nie. Aan die ander kant moet ons ook nie weghardloop met elke nuwe metode -279 - 
wat op die mark kom nie, maar dit wetenskaplik beproef en dit beoordeel nádat ons dit beproef het of ten minste seker gemaak het dat ons weet wat met ' $n$ bepaalde nuwe metode gedoen wil word.

6.2 Ons moet sorg dat ons op hoogte is met wat in die res val Suid-Afrika en in die res van die wereld aan die gang is in hierdie vakgebied. Dit is noodsaaklik dat Gereformeerde Nuwe Testamentici vakkongresse (soos bv. die Nuwe-Testamentiese Werkgemeenskap van Suid-Afrika) bywoon en aktief deelneem aan die werksaamhede van die vakverenigings. Aarı die ander kant mag ons ook nie 'n minderwaardigheidskompleks ontwikkel asof Potchefstroom nie ook 'n sinvolle bydrae kàn makk nie.

Indien ons op hoogte is met wat ander Nuwe-Testamentici doen, sal misverstande in ons eie geledere uitgeskakel word. Baie misverstande berus op onkunde oor tegniese terminologie wat tans algemeen gebruik word. Sonder om hierdie spesifieke sake as sodanig te beredeneer, wil ek twee voorbeelde van sulke misverstande noem:

1. Nida se reseptor-gerigte vertaalmetode het niks met "Amerikaanse reklamepraktyke" te doen waarvolgens "alles in die stryd gewerp sou word om positiewn reaksie by die leser te ontlok" nie. Dit gaan vir Nida oor dieselfde reaksie by vandag se lesers as by die eerste lesers. Of hierdie reaksie positiof of negatief is, is nie ter sake nie.

2. Wanneer daar deur sekere mense in die resepsie-éstetika gesé word dat die leser skeppend betrokke is by die lees van ' $n$ teks, moet nie geïnterpreteer word as ' $n$ aantasting van die leer van die inspirasie van die Skrif nie. 'n Mens sou ook nie op grond van wat in die resepsie-estetika gedoen word kon praat van 'n nuwe teologiese stroming (die "teologie van die reseptor") waarin die evangelie so aangepas moet word "dat dit tog net vir die leser aanvaarbaar kan wees" nie.

6.3 Ons sal ons kenteoretiese vertrekpunte eksplisiet moet makk. Deist (1984:47-56) se kritiek op Lion-Cachet se resensie van sy ABC van Bybeluitleg kom konsekwent hierop neer. Hy beweer dat Cachet met 'n -280 - 
Platonies-realistiese epistemologie werk met trekke van (1) in vermyding van die historiese kader van die Bybel (2) 'n meganiese inspirasieteorie en (3) buitehistoriese Bybeluitleg (soos die rabbynse uitlegmetodes). Ek wil heelhartig met die volgende stelling van Deist (1984:48) saamstem: "Ons (Deist en Cachet - JB) werk met twee uiteenlopende (kenteoretiese - JB) paradigmas ..., en tensy ons dit 'n keer eksplisiet maak, is die kanse op kommunikasie uiters gering." In dieselfde trant skryf Swanepoel (1984:279) in verband met die besinning oor vakfilosofiese uitgangspunte "dat hierdie besinning daarby sal baat as elke deelnemer aan hierdie gesprek sy eie uitgangspunte en metodes eksplisiet maak, en as elkeen hom ook van die teoretiese aannames van die ander deelnemers vergewis. So kan daar sinvol gekommunikeer word."

6.4 Ons sal net eenvoudig interdisslplinêr moèt begin werk as ons enigsins in die toekoms ' $n$ bydrae wil mak. 'n Mens skiet tog nie meer met ' $n$ voorlaaier as daar deesdae masjiengewere op die mark is nie! Combrink (1985:2) bestempel dit as waarskynlik die mees opvallende verskynsel in die studie van die Nuwe Testament in die mees onlangse verlede, dat die bydraes van akademici uit ander dissiplines wat nie self Nuwe Testament-eksegete is nie, 'n belangrike rol gespeel het in die "changing scene of Biblical interpretation."

Palmer (1969:69-70) beklemtoon veral die bydraes vanuit die volgende dissiplines tot die hermeneutiek: filosofie, literatuurwetenskap, soslologie en filologie. Die bekende Nuwe-Testamentikus Anthony Thiselton het sy proefskrif (1980) geskryf oor die waarde van die filosofie vir die teologiese hermeneutiek, en in ' $n$ ander artikel beklemtoon Thiselton (1979:98) dit dat veral die filosofie ' $n$ positiewe bydrae te lewer het tot die verstaan van die Nuwe Testament.

Erickson (1983:257-263) meen dat die bydrae van die linguistiek tot die Nuwe-Testamentiese-wetenskap reeds oortuigend bewys' is maar dat daar steeds nog " $n$ "wide-open field" is vir die studie van linguistiek in die taal van die Bybel. Die Lexicon of the Greek New Testament based on se-

, Vgl. in hierdie verband ook Nida (1972). 
semantic domains van Nida $\varepsilon$ Louw wat DV eersdaags verskyn is 'n konkrete bewys van die bydrae van die linguistiek tot die studie van die Nuwe Testament (vgl. Louw 1979: 108-117).

Wat die literatuurwetenskap betref, val dit in die lig van die huidige problematiek in die hermeneutiese debat (vgl. Lategan, 1984:1-17) nie meer te beredeneer dat dit noodsaaklik vir die Nuwe-Testamentikus is om van hierdie dissipline meer as net die gewone kennis te neem nie. Die boek van Rhoads $\varepsilon$ Mitchie (1982) waarin hulle 'n literère analise van die Markus-evangelie gedoen het, is onder andere ' $n$ konkrete bewys van die bydrae van hierdie dissipline tot die studie van die Nuwe Testament.

Tog meen ek nie dat hierdie interdissiplinère benadering wat ek so sterk bepleit, die eie-aard en uniekheid van die Nuwe-Testamentiese wetenskap as selfstandige dissipline met sy eie veld van ondersoek mag ondermyn nie - hoewel dit nodig is dat die Nuwe-Testamentiese wetenskap dit 'n slag vakfilosofies sal omlyn. Aan die ander kant het ek probeer aantoon dat ' $n$ teksteoretiese benadering (wat dan veral ' $n$ interdissiplinére benadering vereis) nie in beginsel in botsing met die Gereformeerde Skrifbeskouing hoef te wees nie, maar dat juis net die teendeel waar is.

6.5 Ons moet 'n oop oog hè vir die voorlopigheld en die eksperimentele karakter van alle wetenskapsbeoefening as wesenskenmerk van volwaardige wetenskapsbeoefening. Dit is die wetenskaplike se plig om steeds aan te hou eksperimenteer soos wat hy nuwe velde van kennis probeer ontgin. Akademiese stukke (en beslis ook hierdie artikel!) is nie geloofsbelydenisstukke wat een of ander binderide gesag het nie! Die vryheid van die eksegese is nog altyd in Gereformeerde kringe erken.

Aan die ander kant mag die eksperimentele karakter van ons werk ook nooit 'n verskoning wees nie. Navorsingsresultate moet gepubliseer en so aan akademiese diskussie en oorweging onderwerp word.

6.6 Ons moet wak daarteen om nie nie-teologiese tegnieke wat in die uitlegproses gebruik word, direk op teologiese gronde te probeer verdedig of uit teologiese oorwegings te probeer verskans nie. Lategan (1973:153-154) wys daarop dat die histories-kritiese metode op 'n stadium veral in die Duitse teologie as 'n eksklusiewe metode ontwikkel is en ' $n$ 
onafskeidbare onderdeel van die teologiese bedryf geword het. Hierdie eksklusiewe koppeling van in metode en leologie brteken dat die hermeneutiek in praktyk geslote bly vir ander vrugbare ondersoekmetodes. in lllustrasie hiervan is byvoorbeeld die (aanvanklike) negering van die moderne linguistiek deur Duitse teoloë uit die histories-kritiese skool.

Hierdie selfde verarming sou in die Gereformeerde teologie intree as ons op teologlese gronde byvoorbeeld iemand soos Calvyn se hermeneutiek verhef tot die enigste "suiwere en Skrifgetroue" melode en alle metodologiese vernuwing uit beginsel negeer of met groot agterdog bejeën.

Aan die ander kant is dit so dat geen metode uitgangspuntloos toegepas kan word nie (daar is nie so iets soos "n "neutrale" metodologie nie) en ons sal dus steeds ons uitgangspunte moet toets en slyp en aanpas soos wat ons deur die genadige leiding van die Gees tot 'n beter verstaan van God se Woord kom.

\section{BRONNE}

BERKOUWER, G, C, 1967. De Heilige Schrift II. Kampen: Kok.

COETZEE, J.C. 1979, 'n Ou boek in 'n nuwe wèeld of 'n nuwe boek in 'n ou wèreld? In die skriflig 13,4-15.

COETZEE, J.C. 1980. Fila in die literaturu van die Skrifgeleerdes en in die Nuwe Testament. Polchefstroom: $\mathrm{PU}$ vir $\mathrm{CHO}$, Ongepubliseerde klasdiktaat.

COETZEE, J.C., B.J. de Klerk \& L Floor 1980. Die hermeneuse van die Skrif met die oog op hedendaagse kerklik-etiese vraagstukke. In die Skriflig 14/54, 12-26.

COETZEE, J.C. 1981(3). Die Kanon van die Ou nn Nuwe Testamnnt. Potchefstroom: Wesvalia 
COETZEE J.C. 1983. Gedagtestruktuurontleding en basiese struktuurpatrone in die Nuwe Testament. PU vir CHO: Ongepubliseerde klasdiktaat.

COETZEE, J.C. 1984. Die Skrif en die wetenskap: hermeneutiese reëls, in Wetenskap en Woord. Potchefstroom: PU vir CHO. (Potchefstroomse Studies vir Christelike wetenskap $\mathrm{J1:3/1)}$.

COMBRINK, H.J.B. 1983. Die pendulum swaai terug - enkele opmerkinge oor metodes van Skrifinterpretasie. Skrif en Kerk 4(2), 3-15.

COMBRINK, H.J.B. (1986). The changing scene of biblical interpretation, in J.H. Petzer \& P.J. Hartin (eds), A South African perspective on the New Testament. Essays in honour of Bruce M Metzger. Leiden: $E$ J Brill. (Word gepubliseer).

DEIST, F.E. 1984. 'n Kritiese evaluering van die kritiek van F.N. Lion-Cachet. In die Skriflig 18/72, 47-56.

ERICKSON, R.J. 1983. Linguistics and Biblical language: a wide-open field. The Journal of the Fvangelical Theological Society 26, 257-263.

FLOOR, L. 1984. Die verhouding van Ou en Nuwe Testament, in U 1 ig en U warheid. Potchefstroom: PU vir CHO. (Potchefstroomse Studies in Christelike Wetenskap, $J 1: 6 / 4$ ).

HELBERG, J.L. 1983a. Verkjaring en prediking van die Ou Testament. Potchefstroom: Potchefstroomse Teologiese Publikasies.

HELBERG, J.L. 1983b. Die Nuwe Afrikaanse Bybelvertaling: waarom, hoe en vir wie? (Ongepubliseerd).

KRUGER, G $\vee W$ 1975. Inleiding tot die studie van Nuwe Testamentiese Grieks. Stellenbosch: T. Wever.

KUITERT, H. M. 1974. Verslaat Gij wat Gij leest? Over de uftleg van de bijbel. Kampen: Kok. 
LATEGAN, B.C. 1973. Vereistes vir effektiewe N.T. hermeneutiek. NGTT 14, 150-160.

LATEGAN, B.C. 1978. Directions in contemporary exegesis. Between historism and structuralism. Jonrnal of Theology for Southern Africa 25, 18-30.

LATEGAN, B.C. 1984a. Teksteoretiese nitgangspunte. Universiteit van Stellenbosch: Ongepubliseerde klasaantekeninge.

LATEGAN, B.C. 1984b. Current issues in the hermeneutical debate. Neotestamentica 1B, 1-17. (Reading a Text. Source, Recrption, Setling). I.OUW, J.P. 1975. Semantiek van Nuwe-Testamentiese Grieks. Pretoria.

I.OUW, J.P. 1979. The Greek New Testament Wordbook. The Bjble Translator $30,108-117$.

MARSHALL, I.H. 1979. (ed) New Testament Interpretation. Fssays on principles and methods. Exeter: Paternoster.

NIDA, E.A. 1972. Implications of contemporary linguistics for Biblical Scholarship. Journal of Biblical Literature 91, 73-89.

NIXON, R. 1979. The Authority of the New Testament (in Marshall 1979:334-347).

PALMER, R.E. 1969. Hermenellics. Interpretation Theory in Schleinrmacher, Dll they, lleidegger and fadamer. Evanston: Northwestern University Press.

RHOADS, D \& D Mitchie 1982. Mark as Story. An introduct fon to the narrative of a cospel. Philadelphia: Fortress.

RICOEUR, P. 1975. Interprelat Ion Theory. Discourse and the surplus of meaning. Fort Worth: Texas Christian University Press. 


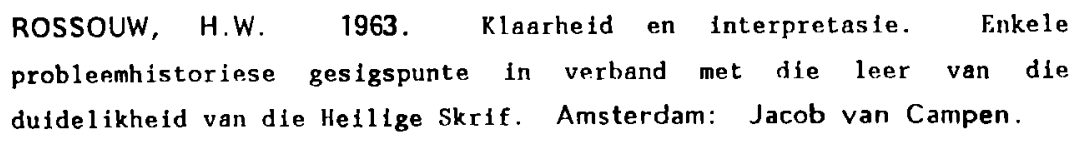

VAN ROOY, H.F. 1981. Historiese kritiek en die Ou Testament. Koers 46, $113-123$.

VORSTER, W.S. 1977. 'n Ou Boek in 'n nuwe wèreld - gedagtes rondom die interpretasie van die Nuwe Testament. Pretoria: Unisa. 